\title{
Gambaran Penggunaan Kontrasepsi Hormonal dan Kejadian Efek Samping Penggunaan Kontrasepsi Hormonal Pada Wanita Usia Subur
}

\author{
Lidia Aditama Putri ${ }^{1)}$; Nurun Nikmah²) \\ 1) Prodi Kebidanan, Universitas Muhammadiyah Gresik, Gresik 61111, Indonesia \\ 2)Program Profesi Bidan, STIKES Ngudia Husada, Bangkalan 69116, Indonesia \\ Corresponding Author: Lidia Aditama Putri \\ E-mail: liydyaputri@umg.ac.id
}

\section{INFORMASI ARTIKEL}

Riwayat Artikel:

Submit : 17-09-2021

Revisi : 27-09-2021

Diterima : 05-10-2021

Publikasi : 30-11-2021

DOI :

http://dx.doi.org/10.30587/ijmt.v1i1.3319

\section{Keywords:}

Hormonal contraception;

Side effect;

Kata Kunci:

Kontrasepsi Hormonal;

Efek samping;

\begin{abstract}
Hormonal contraceptive methods are considered one of the methods with a high level of effectiveness. Although it has high effectiveness, it doesn't mean that hormonal contraceptives are without side effects. The purpose of this study was to describe the use of hormonal contraceptives and their side effects. This type of descriptive research was conducted in MarchMay 20201 at BPM Lilik Nur Hidayati, SST. A total of 80 hormonal family planning acceptors were selected by purposive sampling technique. Data collection was carried out by in-depth interview techniques using interview guidelines. Data analysis using frequency distribution table. The results of this study showed that out of 80 acceptors, almost all of them used 1-month injections (33.8\%), followed by 3-month injections (25\%), combined pills (12.5\%), progestin pills (11.3\%), norplant type implant (10\%), implanon type implant (3.7\%), and jadena type implant (3.75). Meanwhile, the most frequent side effects experienced by the acceptors were weight gain (61.2\%), followed by menstrual disorders (22.5\%), gastrointestinal disorders (10\%), the appearance of black spots (3.8\%), and decreased libido (2.5\%). The use of 1-month injectable contraceptives is the type of contraception that is most in demand by women of childbearing age, while the most common side effect is weight gain.
\end{abstract}

\begin{abstract}
ABSTRAK
Metode kontrasepsi hormonal dianggap salah satu metode dengan tingkat efektifitas yang tinggi. Meskipun memiliki efektivitas yang tinggi, namun bukan berarti alat kontrasepsi hormonal tersebut tanpa efek samping. Tujuan penelitian ini adalah untuk menggambarkan penggunaan alat kontrasepsi hormonal dan efek sampingnya. Jenis penelitian deskriptif, dilakukan pada bulan Maret-Mei 20201 di BPM Lilik Nur Hidayati, SST. Sebanyak 80 akseptor kb hormonal dipilih dengan teknik purposive sampling. Pengambilan data dilakukan dengan teknik wawancara mendalam menggunakan pedoman wawancara. Analisa data menggunakan tabel distribusi frekuensi. Hasil penelitian ini menunjukkan bahwa dari 80 akseptor, hampir seluruhnya menggunakan alat kontrasepsi jenis suntik 1 bulan $(33,8 \%)$, kemudian disusul dengan jenis suntik 3 bulan (25\%), pil kombinasi $(12,5 \%)$, pil progestin $(11,3 \%)$, implant jenis norplant $(10 \%)$, implant jenis implanon $(3,7 \%)$, dan implant jenis jadena $(3,75)$. Sedangkan, efek samping yang paling sering dialami oleh akseptor adalah penambahan berat badan $(61,2 \%)$, kemudian disusul dengan gangguan menstruasi $(22,5 \%)$, gangguan gastrointestinal $(10 \%)$, munculnya flek hitam $(3,8 \%)$, dan penurunan libido $(2,5 \%)$. Penggunaan kontrasepsi suntik 1 bulan merupakan jenis kontrasepsi yang paling banyak diminati wanita
\end{abstract}


usia subur (WUS), sedangkan efek samping terbanyak adalah terjadinya peningkatan berat badan.

\section{PENDAHULUAN}

Keluarga Berencana didefinisikan
sebagai suatu usaha dalam rangka merencanakan jarak dan jumlah kehamilan dengan menggunakan berbagai pilihan alat kontrasepsi (Rusmini, Purwandani, Utami, \& Faizah, 2017) . Kontrasepsi merupakan salah satu upaya meningkatkan keluarga berkualitas. Dari berbagai macam pilihan alat kontrasepsi, kontrasepsi hormonal merupakan pilihan yang masih menjadi primadona di kalangan wanita usia subur, baik itu kontrasepsi hormonal dalam bentuk suntik, pil, ataupun implant. Kontrasepsi hormonal, selain dianggap penggunaannya tidak ribet, juga dianggap sebagai salah satu metode yang efektifitasnya tinggi. Itulah sebabnya pengguna atau akseptor kontrasepsi hormonal ini sangat banyak di kalangan wanita usia subur.

Menurut data terbaru yang dikeluarkan oleh Pusat Data dan Informasi Kementerian Kesehatan RI tahun 2013, tercatat bahwa jumlah peserta KB baru di Indonesia adalah sebanyak 8.500.247 orang dengan sebaran paling banyak ada pada kontrasepsi suntikan yaitu sebanyak 4.128.115 orang, kemudian dilanjutkan dengan kontrasepsi jenis pil 2.261.480 orang, kontrasepsi jenis implant 784.215 orang, IUD (Intra Uterine Device) 658.632 orang, kondom sebanyak 517.638 orang, MOW (Metode Operasi Wanita) 128.793 orang, dan terakhir adalah MOP (Metode Operasi Pria) 21.374 orang (Kemkes RI, 2014)

Untuk Wilayah Jawa Timur, pada tahun 2018 tercatat pengguna KB aktif adalah sebanyak 7.929.796. Dari 7 jutaan peserta KB aktif tersebut, sebanyak 3.046.942 orang merupakan akseptor KB suntikan, sebanyak 1.163.375 orang merupakan akseptor KB pil, sebanyak 710.781 orang merupakan akseptor KB IUD, sebanyak 692.137 orang merupakan peserta KB implant, sebanyak 287.444 orang merupakan akseptor KB MOW, sebanyak 115.399 orang merupakan akseptor KB kondom, dan sebanyak
23.933 orang merupakan akseptor KB MOP (BPS Prov. Jawa Timur, 2019).

Meskipun memiliki efektivitas yang tinggi, namun bukan berarti alat kontrasepsi hormonal ini tanpa efek samping. Beberapa kelemahan dari kontrasepsi hormonal antara lain: (1) terjadinya gangguan pola menstrurasi (menorarghia, bercak/spotting, bahkan amenorrhea); (2) kembalinya kesuburan pasca berhenti kontrasepsi dapat terlambat; (3) terjadinya penambahan berat badan selama pemakaian. Penambahan berat badan yang terjadi bisa disebabkan karena peningkatan selera makan sehingga lemak dalam tubuh bertambah dan/atau bisa disebabkan oleh retensi cairan. Sedangkan pemulihan kesuburan yang terlambat bisa terjadi akibat pengaruh hormon yang belum sepenuhnya terserap oleh tubuh pasca pemakaian (Putri, 2020; Rusmini et al., 2017).

Menurut Hartanto (2010) dan Sety (2017), efek samping kotrasepsi hormonal yang sering terjadi adalah terganggunya siklus mensturasi. Misal, efek samping berupa amenorrhea (berhenti menstruasi) adalah hal yang paling sering terjadi yaitu sebesar $30 \%$. Kemudian disusul dengan terjadi menorarghia dimana darah haid lebih banyak dari biasanya sebesar 35\%, dan/atau dapat pula terjadi spotting yaitu timbul bercak darah di luar siklus mensturasi sebesar 35\%. Efek samping lain yang kecil kemungkinannya terjadi seperti penambahan berat badan (17\%), sakit kepala (10\%), dan/atau dapat pula terjadi efek samping berupa mual ( $8 \%)$.

Pada umumnya efek samping penggunaan kontrasepsi ini bersifat ringan dan biasanya para akseptor masih bisa mentolelir efek samping yang dialaminya. Namun, tidak jarang pula efek samping penggunaan kontrasepsi ini dapat mengganggu kesehatan akseptor sehingga menimbulkkan ketidak- 
nyamanan akseptor dalam melakukan aktivitas sehari-hari, bahkan ada pula efek samping tersebut yang berakibat berat.

Menurut data dari Pusat Data dan Informasi Kementerian Kesehatan RI (2014), terdapat sebanyak 2.548 kasus efek samping kontrasepsi berat yang dialami oleh akseptor KB. Dari data tersebut, komplikasi berat yang sering terjadi akibat penggunaan metode kontrasepsi implant yaitu sebesar $53,3 \%$, kemudian disusul dengan IUD sebesar 40,23\%, MOW sebesar 4,67\%, dan MOP sebesar $1,81 \%$.

Data efek samping tercatat di (Dinkes Kab. Bangkalan (2021) pada tahun 2020 yaitu dari jumlah total 29.430 akseptor KB suntik 3 bulan di Kabupaten Bangkalan yaitu amenorhoe 19.230 (65,34\%), spotting 4.893 (16,63\%), perubahan berat badan 3.696 (12,56\%), pusing $1.217(4,14 \%)$ dan mual muntah 394 (1,34\%). Sedangkan di Puskesmas Bangkalan data efek samping KB suntik 3 bulan yang dialami akseptor KB tercatat yaitu amenorhoe 22 orang $(27,16 \%)$, spotting 18 orang $(22,22 \%)$, perubahan berat badan 17 orang $(20,99 \%)$, pusing 14 orang $(17,28 \%)$ dan mual muntah 10 orang $(12,35 \%)$ (Dinkes Kab. Bangkalan, 2021).

Berdasarkan studi pendahuluan pada tanggal 10 Desember 2021 yang dilakukan oleh peneliti di BPM Lilik Nur Hidayati, SST didapatkan data tentang jumlah akseptor KB hormonal aktif di BPM Lilik Nur Hidayati adalah sebanyak 100 akseptor. Peneliti kemudian melakukan wawancara informal kepada 10 akseptor. Hasil wawancara menunjukkan bahwa, dari 10 orang akseptor tersebut, sebanyak 6 orang (60\%) menggunakan kontrasepsi jenis suntik 1 bulan, 3 orang (30\%) menggunakan kontrasepsi jenis suntik, dan 1 orang sisanya (10\%) menggunakan pil kombinasi. Kemudian peneliti juga berhasil menghimpun data tentang efek samping yang dialami oleh akseptor tersebut, yaitu antara lain 30\% mengalami amenorrhea, 40\% mengalami spotting, dan 30\% mengalami kenaikan berat badan. Lebihdari 50\% akseptor tersebut merasa tidak nyaman terhadap efek samping yang mereka alami, namun mereka mengatakan tetap menjalaninya karena tidak ingin mengambil risiko dengan mengganti metode kontrasepsi lain.

Efek samping kontrasepsi hormonal terjadi karena pengaruh pemberian hormon yang dimasukkan ke tubuh akseptor. Efek samping penggunaan kontrasepsi hormonal ini berbeda pada setiap orang. Contoh, kontrasepsi hormonal dengan kandungan hormon progestin pada umumnya dapat mengubah siklus menstruasi. Kemudian, jenis kontrasepsi hormonal yang mengandung hormon estrogen pada umumnya dapat menyebabkan terjadinya bercak atau flek hitam pada wajah. Efek samping lain yang menyebabkan ibu tidak percaya diri dan tidak nyaman adalah penambahan berat badan selama pemakaian kontrasepsi hormonal, baik itu jenis tunggal maupun kombinasi (Sety, 2017).

Sebenarnya, efek samping dari penggunaan kontrasepsi ini pada umumnya bersifat ringan dan berlangsung pada awal mensturasi. Namun demikian, ada juga beberapa orang yang mengalami efek samping berat dan/atau berkepanjangan.

Oleh karenanya, maka petugas kesehatan atau bidan diharapkan dapat meningkatkan KIE (Komunikasi Informasi dan Edukasi) yang lebih efektif tentang dampak atau efek samping penggunaan kontrasepsi hormonal kepada calon akseptor sehingga bisa mereka lebih memahami dan menerima kondisi-kondisi perubahan kesehatan yang mungkin dialami ketika menggunakan alat kontrasepsi hormonal tertentu serta mewaspadai apabila terjadi efek samping yang bersifat membahayakan.

Penelitian ini bertujuan untuk memberikan gambaran tentang penggunaan kontrasepsi hormonal dan efek samping penggunaan alat kontrasepsi hormonal pada wanita usia subur. 


\section{METODE}

Penelitian ini merupakan jenis penelitian deskriptif. Penelitian ini dilakukan di PMB Lilik Nur Hidayati, SST yang bertempat di Kabupaten Bangkalan. Penelitian dilakukan pada bulan Maret hingga Mei 2021. Populasi dalam penelitian ini adalah seluruh wanita usia subur yang menjadi akseptor kontrasepsi hormonal di PMB Lilik Nur Hidayati, SST. Sebanyak 80 orang dipilih menjadi sampel penelitian dengan menggunakan teknik purposive sampling.

Data tentang karakteristik pasien dan efek samping kontrasepsi dalam penelitian ini diambil menggunakan kuisioner dan observasi langsung melalui wawancara. Analisis data dalam penelitian ini menggunakan tabel distribusi frekuensi.

\section{HASIL PENELITIAN}

\section{Gambaran Umum Lokasi Peneltian}

Penelitian dilakukan di BPM Lilik Nur Hidayati yang memiliki sertifikasi sebagai bidan delima. Terletak di Jl. Raya Burneh Kecamatan Bangkalan, Kabupaten Bangkalan. BPM ini terdiri dari 1 ruang periksa, 1 ruang tunggu dan administrasi, 1 ruang tindakan, 3 ruang perawatan, 1 kamar mandi pasien, dan 1 ruang pojok ASI. Melayani persalinan umum, BPJS kesehatan. Memiliki 4 orang tenaga bidan.

\section{Karakteristik Responden Penelitian}

Tabel 1. Distribusi Frekuensi Responden Penelitian Berdasarkan Umur

\begin{tabular}{ccc}
\hline Umur & Frekuensi (F) & Persentase $(\%)$ \\
\hline$<25$ tahun & 35 & 43,8 \\
$26-30$ tahun & 16 & 20 \\
$31-35$ tahun & 12 & 15 \\
$>36$ tahun & 17 & 21,2 \\
\hline Total & 80 & 100 \\
\hline
\end{tabular}

Sumber: Data Primer, 2021

Berdasarkan tabel 1 di atas dapat terlihat bahwa hampir seluruhnya responden penelitian berusia kurang dari 25 tahun, yaitu sebanyak 35 orang $(43,8 \%)$.
Tabel 2. Distribusi Frekuensi Responden Penelitian Berdasarkan Jumlah Anak

\begin{tabular}{ccc}
\hline Jumlah Anak & Frekuensi $(\mathrm{F})$ & Persentase $(\%)$ \\
\hline 1-2 Anak & 21 & 26 \\
3-4 Anak & 54 & 67,5 \\
$\geq$ 5 Anak & 5 & 6,3 \\
\hline Total & 80 & 100
\end{tabular}

Sumber: Data Primer, 2021

Berdasarkan tabel 2 menunjukkan bahwa sebagian besar responden memiliki 3-4 orang anak, yaitu sebanyak 54 orang $(67,5 \%)$.

Tabel 3. Distribusi Frekuensi Responden Penelitian Berdasarkan Tingkat Pendidikan

\begin{tabular}{ccc}
\hline Pendidikan & Frekuensi $(\mathrm{F})$ & Persentase $(\%)$ \\
\hline SD $/$ Ml & 41 & 51,3 \\
SMP/SLTP & 18 & 22,5 \\
SMA/SLTA & 12 & 15 \\
PT & 9 & 11,2 \\
\hline Total & 80 & 100
\end{tabular}

Sumber: Data Primer, 2021

Hasil data dari tabel 3 menunjukkan bahwa sebagian besar responden adalah lulusan Sekolah Dasar (SD) atau Madrasah Ibtidaiyah (MI), yaitu sebanyak 41 orang $(51,3)$.

Tabel 4. Distribusi Frekuensi Jumlah Akseptor KB Hormonal

\begin{tabular}{ccc}
\hline $\begin{array}{c}\text { Jenis } \\
\text { Kontrasepsi }\end{array}$ & Frekuensi (F) & Persentase (\%) \\
\hline Pil & & \\
Kombinasi & 10 & 12,5 \\
Progestin & 9 & 11,3 \\
Suntik & & \\
1 bulan & 27 & 33,8 \\
3 bulan & 20 & 25 \\
Implant & & \\
Norplant & 8 & 10 \\
Implanon & 3 & 3,7 \\
Jadena & 3 & 3,7 \\
\hline Total & 80 & 100 \\
\hline
\end{tabular}

Sumber: Data Primer, 2021

Tabel 4 menunjukkan bahwa jumlah akseptor KB hormonal yang terbanyak adalah pada kontrasepsi jenis suntik 1 bulan. Hampir seluruhnya $(33,8 \%)$ responden menggunakan KB suntik 1 bulan, yaitu sebanyak 27 orang. 


\section{Efek Samping Penggunakan Kontrasepsi Hormonal}

Berikut ini merupakan beberapa jenis efek samping yang dialami responden selama memakai kontrasepsi jenis hormonal (Tabel 5).

Tabel 5. Distribusi Frekuensi Efek Samping Penggunaan Kontrasepsi Hormonal

\begin{tabular}{lcc}
\hline \multicolumn{1}{c}{$\begin{array}{c}\text { Jenis Efek } \\
\text { Samping }\end{array}$} & Frekuensi (F) & Persentase (\%) \\
\hline Peningkatan BB & 49 & 61,2 \\
$\begin{array}{l}\text { Gangguan } \\
\text { menstruasi }\end{array}$ & 18 & 22,5 \\
$\begin{array}{l}\text { Gangguan } \\
\text { gastrointestinal }\end{array}$ & 8 & 10 \\
$\begin{array}{l}\text { Penurunan libido } \\
\begin{array}{l}\text { Munculnya acne } \\
\text { dan flek hitam }\end{array}\end{array}$ & 2 & 2,5 \\
\hline \multicolumn{1}{c}{ Total } & 3 & 3,8 \\
\hline
\end{tabular}

Sumber: Data Primer, 2021

Berdasarkan tabel 5 menunjukkan bahwa sebagian besar responden mengalami efek samping dari penggunaan kontrasepsi hormonal berupa kenaikan berat badan, yaitu sebanyak 49 orang $(61,2)$. Hal ini berarti bahwa peningkatan berat badan merupakan efek yang paling sering dialami oleh akseptor KB hormonal.

Tabel 6. Distribusi Frekuensi Responden Penelitian Berdasarkan Berat Badan Sebelum dan Setelah Menggunakan Kontrasepsi Hormonal

\begin{tabular}{ccccc}
\hline Berat & \multicolumn{2}{c}{ Sebelum } & \multicolumn{2}{c}{ Sesudah } \\
\cline { 2 - 5 } $\begin{array}{c}\text { Badan } \\
(\mathrm{Kg})\end{array}$ & $\Sigma$ & $\%$ & $\Sigma$ & $\%$ \\
$\leq 40-49$ & 25 & 31,2 & 15 & 18,7 \\
$50-59$ & 35 & 43,8 & 30 & 37,5 \\
$60-69$ & 15 & 18,8 & 26 & 32,5 \\
$\geq 70$ & 5 & 6,3 & 9 & 11,3 \\
\hline Total & 80 & 100 & 80 & 100 \\
\hline
\end{tabular}

Sumber: Data Primer, 2021

Berdasarkan tabel 6 menunjukkan bahwa sebelum maupun setelah menggunakan kotrasepsi hormonal hampir seluruhnya responden memiliki berat badan antara 50-59 kg. Akan tetapi, jika dianalisis lebih lanjut, terlihat bahwa terjadi peningkatan yang signifikan terhadap perubahan berat badan responden setelah menjadi akseptor KB hormonal.

\section{PEMBAHASAN}

Berdasarkan tabel 4 Sebagian besar akseptor memakai jenis alat kontrasepsi suntik di BPM Lilik Nur Hidayati, SST Bulan Maret - Mei Tahun 2021 adalah jenis KB suntik 1 bulan sebanyak 27 orang $(57,4 \%)$, kemudian disusul dengan jenis KB suntik 3 bulan sebanyak 20 orang $(25 \%)$.

Kontrasepsi jenis suntik merupakan salah satu metode yang digunakan untuk mencegah kehamilan dan selalu menjadi primadona di kalangan negara-negara berkembang. Cara kerja kontrasepsi suntik dalam mencegah kehamilan adalah dengan membauat dinding uterus menjadi lebih kental sehingga sperma sulit menembusnya untuk melakukan pembuahan. Selain itu, kontrasepsi jenis sunik juga bekeja dengan cara mencegah ovum (sel telur) yang sudah dibuahi menempel ke dinding uterus sehingga proses kehamilan dapat dicegah (Matahari, Utami, \& Sugiharti, 2018).

Kontrasepsi suntik merupakan salah satu metode kontrasepsi jenis hormonal yang mampu mencegah terjadinya kehamilan hingga mencapai 99\% (Rusmini et al., 2017). Inilah yang menjadi salah satu alasan mengapa kontrasepsi jenis suntik banyak sekali peminatnya. Selain itu, penggunaan kontrasepsi suntik yang tidak ribet karena hanya dengan sekali suntikan, maka hingga 1 atau 3 bulan bisa bebas melakukan hubungan seksual tanpa harus menggunakan pengaman. Harganya yang murah juga salah satu hal yang menjadi nilai lebih.

Ada dua jenis kontrasepsi suntik, pertama adalah jenis suntik 1 bulan dan jenis kb suntik 3 bulan. Kontrasepsi suntuk 1 bulan merupakan jenis KB yang disuntikkan setiap sebulan sekali dengan dosis $1 \mathrm{ml}$. Kontrasepsi suntik 1 bulan disebut pula dengan istilah suntik kombinasi, karena suntikan kontrasepsi 1 bulan ini mengandung hormon kombinasi yaitu hormon estrogen (Estradiol Cypionate) dan progestron. Penyuntikan pertama untuk kontrasepsi kombinasi pada akseptor baru dilakukan pada saat mensturasi hari ke-7 atau setelah 6 minggu 
pasca melahirkan dengan terlebih dahulu memastikan bahwa ibu tidak sedang hamil.

Jenis kontrasepsi suntik yang kedua adalah kontrasepsi suntik 3 bulan yang disuntikkan kepada akseptor setiap tiga bulan sekali (12 minggu). Kandungan hormon dalam kontrasepsi jenis suntik 3 bulan adalah hormon progesterone (DMPA / Medroxyprogesterone Acetate). Terdapat dua jenis pilihan dosis pada kontrasepsi suntik 3 bulan, yaitu dosis $1 \mathrm{ml}$ atau $3 \mathrm{ml}$. Sama halnya dengan kontrasepsi suntik kombinasi, kontrasepsi 3 bukan diberikan pada saat mensturasi hari ke-7 atau saat 6 minggu pasca persalinan dan dipastikan ibu tidak sedang hamil untuk diberikan pada akseptor baru (Pratiwi, Syahredi, \& Erkadius, 2014).

Kontrasepsi jenis suntik dapat diberikan pada ibu menyusui asalkan dipastikan ibu tidak hamil dan diberikan minimal pada saat 6 minggu pasca persalinan. Biasanya, jenis KB suntik 3 bulan lebih aman diberikan kepada ibu menyusui karena lebih rendah efeknya terhadap produksi ASI dibandingkan dengan KB suntik 1 bulan (Pratiwi et al., 2014).

Dari kedua jenis ini, kontrasepsi jenis suntik 1 bulan lebih banyak diminati di kalangan wanita usia subur. Hal ini disebabkan karena (1) jenis kontrasepsi suntik 1 bulan tidak mengganggu mensturasi; (2) efek penambahan berat badan yang dirasakan oleh wanita usia subur tidak begitu signifikan; (3) kembalinya kesuburan pada wanita pasca berhenti suntik KB 1 bulan lebih cepat dibandingkan dengan suntik 3 bulan.

Hal ini sesuai dengan pendapat Putri (2020) dalam penelitian menyimpulkan bahwa kembalinya kesuburan wanita pasca berhenti menggunakan KB suntik 1 bulan adalah $<6$ bulan, sedangkan untuk bisa hamil lagi rata-rata membutuhkan waktu 6-12 bulan pada wanita dengan riwayat kontrasepsi suntik 3 bulan.

Penelitian lain yang dilakukan oleh Nabila, Nikmatul, \& Rifa'i (2014) mengemukakan bahwa hanya sedikit efek samping yang dialami wanita berupa kenaikan berat badan. Penelitian yang dilakukan oleh Pratiwi et al. (2014) menyimpulkan bahwa keluha efek samping yang paling sering dialami oleh akseptot KB jen suntik 3 bulan adalah amenorrhea dan kenaikan berat badan.

Menurut Matahari et al. (2018), ada banyak keuntungan yang didapatkan ketika WUS menggunakan KB jenis suntik 1 bulan, yaitu efektivitasnya tinggi, tidak perlu menyimpan obat suntik di rumah karena ada petugas kesehatan yang langsung memberikan tindakan, dalam penggunaannya tidak melakukan pemeriksaan dalam vagina, harganya juga relatif murah.

Bagi pengguna kontrasepsi suntik 1 bulan, ada beberapa kerugian yang mungkin terjadi yaitu adanya gangguan mensturasi seperti spotting, perdarahan mensturasi yang tidak teratur, menorarghia, hingga amenorrhea. Keluhan lain yang dapat terjadi yaitu sakit kepala, nyeri payudara ringan, mual, yang akan hilang biasanya setelah WUS mendapatkan suntikan kedua atau ketiga (Matahari et al., 2018; Nabila et al., 2014).

Pengguna kontrasepsi suntik 3 bulan juga mungkin mengalami efek samping terutama saat awal penggunaan, seperti terjadinya amenorrhea, mensturasi tidak teratur dan/atau berkepanjangan, terjadi penambahan berat badan, sakit kepala, nyeri pada payudara, perut kembung, mengalami tumbuhnya jerawat pada wajah, dan perubahan suasana hati. Kembalinya kesuburan wanita saat berhenti menggunakan KB suntik 3 bulan dapat berlangsung lebih lama, serta wanita dengan riwayat KB suntik 3 bulan dapat memicu terjadinya risiko osteoporosis.

Keuntungan akseptor yang menggunakan KB suntik jenis 3 bulan juga cukup banyak, yaitu antara lain: (1) tidak mempengaruhi produksi ASI, mengurangi risiko penyakit jantung dan gangguan pembekuan darah karena tidak mengandung hormon estrogen, mencegah kehamilan ektopik dan mencegah kanker endometrium, serta penyakit radang panggul. 
Berdasarkan tabel 4 Akseptor memakai jenis alat kontrasepsi pil di BPM Lilik Nur Hidayati, SST Bulan Maret - Mei Tahun 2021 adalah kombinasi sebanyak 10 orang (52,6\%).

Kontrasepsi oral atau yang lebih dikenal dengan sebutan kontrasepsi pil adalah merupakan salah satu jenis kontrasepsi dalam bentuk tablet yang diminum oleh akseptor sehari sekali 1 tablet. Dalam 1 strip kontrasesi pil, pada umumnya terdapat 30 tablet dimana 21 tablet berisi hormon kombinasi (progesterone dan estrogen), sedangkan 7 tablet lainnya hanya berisi placebo.

Kontrasepsi pil bekerja dengan cara mencegah implantasi hasil pembuahan pada uteus, menekan terjadinya ovulasi, mengentalkan lendir serviks sehingga sperma tidak mudah masuk, mengganggu pergerakan tuba fallopii sehingga transportasi sel telur di saluran tuba menjadi terhambat (Hartanto, 2010).

Beberapa keuntungan yang didapatkan oleh akseptor yang menggunakan kontrasepsi pil antara lain: (1) mudah dihentikan penggunaannya oleh akseptor sendiri; (2) tidak mengganggu hubungan seksual; (3) penggunaan kontrasepsi pil dapat diminum dalam jangka panjang; (4) kesuburan pasca berhenti memakai kontrasepsi pil cepat kembali. Sedangkan beberapa kekurangan yang dialami oleh akseptor kontrasepsi pil antara lain: (1) kontraindikasi bagi ibu yang menyusui, (2) tidak mencegah HIV (Human Immunodeficiency Virus) IMS (Infeksi Menular Seksual), (3) terkadang akseptor sering lupa karena harus meminumnya setiap saat; (4) terkadang akseptor juga merasa bosan meminum obat setiap hari (Matahari et al., 2018).

Efek samping yang sering terjadi pada pengguna pil KB adalah mual pada saat awal pemakaian, kemudian efek samping lainnya yaitu timbulnya jerawat, migraine, sakit kepala ringan, perubahan suasana hati, dan penambahan berat badan. Hal ini sesuai dengan penelitian yang dilakukan oleh Caecilia et al. (2020), efek samping pil KB yang paling banyak dirasakan oleh akseptor adalah penambahan berat badan dan sakit kepala ringan (Matahari et al., 2018).

Kontrasepsi pil merupakan jenis kontrasepsi kedua yang banyak digunakan oleh responden dalam penelitian ini, begitu pula oleh masyarakat Indonesia pada umumnya. Kontrasepsi pil banyak menjadi pilihan wanita usia subur dengan alasan utama yaitu murah dan mudah didapat serta tidak perlu pergi ke tenaga kesehatan untuk menggunakannya. Selain itu, alasan lainnya adalah penggunaan pil KB tidak menimbulkan efek samping berupa lambatnya kembali kesuburan sehingga wanita dapat segera hamil kembali saat berhenti meminum pil.

Hal ini sesuai dengan penelitian yang dilakukan oleh Baharu, Harismayanti, \& Naue (2019) yang menyimpulkan bahwa kontrasepsi pil banyak menjadi pilihan wanita usia produktif (20-30 tahun) sebab mereka dapat dengan mudah kembali subur apabila berhenti menggunakan pil KB untuk mengatur jarak kehamilan.

Berdasarkan tabel 5.7 Sebagian besar akseptor memakai jenis alat kontrasepsi Implan di BPM Lilik Nur Hidayati, SST Bulan Maret-Mei Tahun 2021 adalah Norplant sebanyak 8 orang (57,1\%).

Kontrasepsi jenis implant merupakan alat yang terbuat dari karet lunak berbentuk tabung silindris kecil dan berisi hormon sintetik (progesteron). Kapsul implant dimasukkan melalui operasi kecil di bawah kulit pada lengan atas wanita. Oleh karena itu, kontrasepsi implant sering disebut dengan AKBK (Alat Kontrasepsi Bawah Kulit), sedangkan orang awam sering menyebutnya sebagai KB "susuk" (Matahari et al., 2018).

Kontrasepsi implant memiliki beberapa keunggulan, yaitu antara lain: (1) kontrasepsi implant merupakan salah satu jenis kontrasepsi jangka panjang sebab akseptor KB implan dapat mencegah terjadinya kehamilan dalam jangka waktu 5 tahun dalam sekali pemasangan; (2) 
kontrasepsi implant juga memiliki efektifitas yang tinggi; (3) Jika kapsul implant dicabut, maka kesuburan wanita juga akan cepat kembali; (4) pemasangan kapsul implant juga tidak memerlukan pemeriksaan dalam (pemeriksaan vagina); (5) tidak menyebabkan produksi ASI terhambat; (6) tidak mengganggu hubungan seksual; (7) dan pasien tidak perlu ke klinik/bidan/dokter lagi untuk jangka waktu yang lama (Rusmini et al., 2017).

Selain keuntungan kontrasepsi tersebut diatas, pemasangan implant juga memiliki beberapa keuntungan non kontrasepsi antara lain: (1) mengurangi jumlah darah haid dan nyeri haid; (2) menurunkan kejadian kanker endometrium; (3) melindungi terjadinya kanker payudara; (4) mengurangi risiko terjadinya anemia; (5) menurunkan risiko radang panggul dan endometriosis (Rusmini et al., 2017).

Kontrasepsi jenis implant memiliki beberapa keterbatasan, diantaranya adalah gangguan pola haid seperti spotting, hipermenorhea, hingga amenorrhea. Selain itu, keluhan lain dapat berupa peningkatan atau penurunan berat badan, nyeri pada payudara, sakit kepala ringan, gelisah dan perubahan mood, serta mual. Keterbatasan non kontrasepsi pada implan adalah akseptor tidak dapat mencabut sendiri kapsul implannya apabila ingin menghentikan pemakaian, akseptor harus pergi ke klinik/bidan/dokter kandungan untuk bisa dilakukan tindakan pencabutan maupun pemasangan (Rusmini et al., 2017).

Akseptor KB implant pada umumnya memilih jenis kontrasepsi ini karena impant memiliki efek jangka panjang yang membuat wanita tidak harus pergi ke pelayanan kesehatan setiap waktu untuk dapat mencegah kehamilan. Pernyataan ini sesuai dengan penelitian yang dilakukan oleh Susilawati, Heryani, Artikasari, \& Pransiska (2021) yang menyatakan bahwa alasan utama calon akseptor KB memilih jenis implant adalah karena memiliki efektivitas jangka panjang.

Berdasarkan tabel 5 Sebagian besar Akseptor di BPM Lilik Nur Hidayati, SST mengalami efek samping kontrasepsi hormonal berupa peningkatan berat badan 49 orang $(61,2 \%)$.

Sebagian besar akseptor mengalami peningkatan berat badan sebanyak 4-10 kilogram selama penggunaan kontrasepsi hormonal. Menurut Matahari et al. (2018); Nabila et al. (2014); Pratiwi et al., (2014) penambahan berat badan ini mungkin terjadi karena tubuh wanita memiliki kelebihan hormon estrogen sehingga menyebabkan pengeluaran air dan natrium didalam tubuhnya menjadi berkurang (hal ini disebut retensi cairan). Pada kontrasepsi jenis hormonal yang mengandung progesterone, hal ini dapat memicu penambaha berat badan sebab progesterone juga akan memingkatkan rangsangan karbohidrat menjadi gula dan lemak. Alasan lain yang mungkin adalah karena kontrasepsi jenis hormonal ini umumnya memiliki efek samping berupa peningkatan nafsu makan, maka besar kemungkinan berat badan akseptor menjadi naik apabila akseptor kemudian tidak memiliki pola makan tinggi karbohidrat dan lemak serta tinggi gula.

Selain penambahan berat badan, efek samping penggunaan kontrasepsi hormonal yang sering terjadi adalah gangguan pola mensturasi $(22,5 \%)$, baik itu berupa spotting, amenorrhea, menorarghia, dan sebagainya. Menurut penelitian yang dilakukan oleh Sety (2017) menyimpulkan bahwa penggunaan kontrasepsi hormonal mulai dari pil, suntik, hingga implant dapat menyebabkan terjadinya gangguan siklus maupun pola menstrurasi.

Efek samping lain yang mungkin terjadi adalah gangguan gastrointestinal berupa mual (10\%), hal ini biasanya terjadi pada saat awal penggunaan kontrasepsi hormonal dan kemudian akan menghilang setelah tubuh mulai bisa beradaptasi dengan hormon yang masukkan ke dalam tubuh. Selain itu, efek samping lain dapat berupa timbulnya fek hitam dan jerawat $(3,8 \%)$ serta terjadinya penurunan gairah seks $(2,5 \%)$.

Setiap jenis kontrasepsi hormonal memiliki keuntungan dan kelebihannya masing masing, serta memiliki efek samping yang 
berbeda-beda. Maka kegiatan konseling Keluarga Berencana (KB) mengenai jenis kontrasepsi perlu dilakukan pada awal penggunaan kontrasepsi agar akseptor memahami tentang kelebihan, kekurangan, serta efek samping dari kontrasepsi yang dipilihnya. Konseling dan pendampingan yang dilakukan oleh petugas kesehatan berdasarkan efek samping yang dialami akseptor juga diperlukan untuk mencegah terjadinya drop out.

\section{SIMPULAN}

Penggunaan kontrasepsi hormonal di kalangan wanita usia subur masih mendominasi. Jenis kontrasepsi hormonal yang paling banyak digunakan oleh akseptor adalah jenis KB suntik 1 bulan (suntikan kombinasi hormon estrogen dan progesteron). Dari penggunaan kontrasepsi hormonal tersebut terdapat beberapa efek samping yang dialami oleh akseptor. Efek samping kontrasepsi hormonal yang sering terjadi adalah peningkatan berat badan.

\section{UCAPAN TERIMA KASIH}

Terimakasih kepada Ibu Lilik Nur Hidayati, SST. yang telah memberikan izin untuk melakukan penelitian di tempat praktiknya.

\section{DAFTAR PUSTAKA}

Baharu, M. R., Harismayanti, H., \& Naue, A. K. (2019). Faktor-Faktor Yang Berhubungan Dengan Peminatan Kontrasepsi Pil Dan Suntik Di Wilayah Kerja Puskesmas Global Tibawa. Akademika: Jurnal Ilmiah Media Publikasi Ilmu Pengetahuan Dan Teknologi, 8(1), $\quad 54$. https://doi.org/10.31314/akademika.v8i1. 298

BPS Prov. Jawa Timur. (2019). Jumlah Pasangan Usia Subur dan Peserta KB Aktif di Provinsi JawaTimur Menurut Kabupaten/Kota, 2018. Retrieved February 14, 2021, from Badan Pusat Statistik Provinsi Jawa Timur website:

https:/ / jatim.bps.go.id/statictable/2019/ 10/09/1683/jumlah-pasangan-usia-subur- dan-peserta-kb-aktif-di-provinsi-

jawatimur-menurut-kabupaten-kota-2018.html

Caecilia, M., Setiawati, N., Prasetyaningrum, E., Alit, D., Tinggi, S., Farmasi, I., \& Pharmasi, Y. (2020). Efek Samping Pil KB Akseptor di Lingkungan Manyaran Kota Semarang. Cendekia Journal Of Pharmacy, 4(2), 175184.

Dinkes Kab. Bangkalan. (2021). Laporan Keluarga Berencana dan Kontrasepsi Dinas Kesehatan Kabupaten Bangkalan 2020. Bangkalan.

Hartanto, H. (2010). Keluarga Berencana dan Kontrasepsi. Yogyakarta: Pustaka Sinar Harapan.

Matahari, R., Utami, F. P., \& Sugiharti, S. (2018). Buku Ajar Keluarga Berencana Dan Kontrasepsi. Pustaka Ilmu, viii+104 halaman. Retrieved from http://eprints.uad.ac.id/24374/1/buku ajar Keluarga Berencana dan Kontrasepsi.pdf

Nabila, L., Nikmatul, I., \& Rifa'i. (2014). Gambaran Kejadian Efek Samping Pada Akseptor Kb Suntik 1 Bulan Di Desa Denanyar Kecamatan Jombang Kabupaten Jombang. 6.

Pratiwi, D., Syahredi, S., \& Erkadius, E. (2014). Hubungan Antara Penggunaan Kontrasepsi Hormonal Suntik DMPA dengan Peningkatan Berat Badan di Puskesmas Lapai Kota Padang. Jurnal Kesehatan Andalas, 3(3), 365-369. https://doi.org/10.25077/jka.v3i3.130

Pusat Data dan Informasi Kementerian Kesehatan RI. (2014). InfoDATIN : Situasi dan Analisis Keluarga Berencana. Pusat Data Dan Informasi Kementerian Kesehatan RI, pp. 1-6.

Putri, L. A. (2020). Perbedaan Pemulihan Tingkat Kesuburan Pada Wanita dengan Riwayat Kontrasepsi Suntik 1 Bulan dan Suntik 3 Bulan di BPM Meiyuni Kota Bangkalan. Jurnal Warta Bhakti Husada Mulia, 5-24.

Rusmini, Purwandani, S., Utami, V. N., \& Faizah, S. N. (2017). Pelayanan KB dan Kesehatan Reproduksi. Jakarta: Trans Info Media. 
Sety, L. M. (2017). Jenis Pemakaian Kontrasepsi Hormonal Dan Gangguan Menstruasi Di Wilayah Kerja Puskesmas. Jurnal Kesehatan, 5(1), 60-66. Retrieved from https://ejurnal.poltekkes-

tjk.ac.id/index.php/JK/article/viewFile/6 $7 / 60$

Susilawati, E., Heryani, N., Artikasari, L., \& Pransiska, E. (2021). Factors Associated with the Selection of Contraceptive Implants for Family Planning Acceptors in Jambi City. Jurnal Kesehatan Komunitas, $7(2)$, 189-195. https: //doi.org/10.25311/keskom.vol7.iss 2.928 